\title{
Vibrational spectroscopy investigation using M06-2X and B3LYP methods analysis on the structure of 2-Trifluoromethyl-10H- benzo[4,5]-imidazo[1,2-a]pyrimidin-4-one
}

\author{
Yusuf Sert ${ }^{\mathrm{a}, \mathrm{b}, *}$, M. Mahendra ${ }^{\mathrm{c}}$, Chandra ${ }^{\mathrm{c}}$, K. Shivashankar ${ }^{\mathrm{d}}$, K.B. Puttaraju ${ }^{\mathrm{d}}$, H. Doğan ${ }^{\mathrm{a}}$, Çagrı Çırak ${ }^{\mathrm{e}}$, \\ Fatih Ucun ${ }^{\mathrm{f}}$
}

${ }^{a}$ Department of Physics, Faculty of Art E Sciences, Bozok University, Yozgat 66100, Turkey

b Sorgun Vocational School, Bozok University, Yozgat 66100, Turkey

${ }^{\mathrm{c}}$ Department of Studies in Physics, Manasagangotri, University of Mysore, Mysore 570 006, India

${ }^{\mathrm{d}}$ P.G. Department of Chemistry, Central College Campus, Bangalore University, Bangalore 560001 , India

e Department of Physics, Faculty of Art E Sciences, Erzincan University, Erzincan 24100, Turkey

${ }^{\mathrm{f}}$ Department of Physics, Faculty of Art E' Sciences, Süleyman Demirel University, Isparta 32100, Turkey

\section{H I G H L I G H T S}

- The FT-IR and Laser-Raman spectra of the title compound were recorded in solid phase.

- The optimized geometry and vibrational frequencies were calculated for the first time.

- The HOMO-LUMO energies and related molecular properties were evaluated.
G R A P H I C A L A B S T R A C T

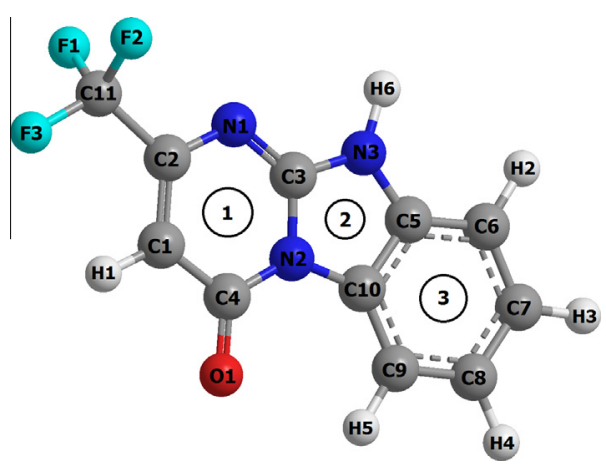

\begin{abstract}
A B S T R A C T
In this study, the experimental and theoretical vibrational frequencies of a newly synthesized bioactive agent namely, 2-Trifluoromethyl-10H-benzo[4,5]-imidazo[1,2-a]pyrimidin-4-one (TIP) have been investigated. The experimental FT-IR (4000-400 $\left.\mathrm{cm}^{-1}\right)$ and Laser-Raman spectra $\left(4000-100 \mathrm{~cm}^{-1}\right)$ of the molecule in solid phase have been recorded. The theoretical vibrational frequencies and the optimized geometric parameters (bond lengths and bond angles) have been calculated using density functional theory (DFT/B3LYP: Becke, 3-parameter, Lee-Yang-Parr) and M06-2X (the highly parametrized, empirical exchange correlation function) quantum chemical methods with $6-311++G(d, p)$ basis set by Gaussian $09 \mathrm{~W}$ software, for the first time. The assignments of the vibrational frequencies have been done by potential energy distribution (PED) analysis using VEDA 4 software. The theoretical optimized geometric parameters and vibrational frequencies have been found to be in good agreement with the corresponding experimental data and results in the literature. In addition, the highest occupied molecular orbital (HOMO) energy, the lowest unoccupied molecular orbital (LUMO) energy and the other related molecular energy values of the compound have been investigated using the same theoretical calculations.
\end{abstract}

(c) 2014 Elsevier B.V. All rights reserved.

\footnotetext{
* Corresponding author at: Department of Physics, Faculty of Art \& Sciences, Bozok University, Yozgat 66100, Turkey. Tel.: +90 3542421021 ; fax: +90 3542421022.

E-mail address: yusufsert1984@gmail.com (Y. Sert).
} 


\section{Introduction}

Our ongoing research in the field of synthesis and biological evaluation on the dihydrobenzo[4,5]imidazo[1,2-a]pyrimidin-4one fused class of molecules have gained much importance, owing to broad spectrum and wide range of interesting biological activities of the benzimidazole [1,2] and the pyrimidine [3,4]. Hence the fusion of benzimidazole and pyrimidine pharmacophores in a single molecular frame work and its influence on the biological activities are of immense interest; and had become a subject of our study in the recent times. In our previous work [5], we have shown by in vitro that the benzo[4,5]imidazo[1,2-a]pyrimidin-4-one derivatives have given significant antibacterial, antifungal and anticancer activities and were proven to be highly potent active molecules than the standard drugs available in the market. In view of this background and from the literature survey, which reveals that to the best of our knowledge; the results based on quantum chemical calculations, FT-IR and Laser-Raman spectral studies and HOMO-LUMO analysis on the compound 2-Trifluoromethyl10H-benzo[4,5]-imidazo[1,2-a]pyrimidin-4-one (TIP) have not been reported elsewhere. Herein, we reported detailed interpretation of the infrared and Raman spectra based on the experimental and theoretical results, which are acceptable and supportable to each other. The structure of title molecule has been also studied by single crystal X-ray diffraction [6]. In this work, the theoretical and experimental studies have been performed to give a detailed definition of the optimized molecular structure and vibrational frequencies of the title molecule.

\section{Experimental details}

FT-IR spectrum (4000-400 $\mathrm{cm}^{-1}$ ) of the title molecule has been recorded by Perkin-Elmer Spectrum Two FT-IR Spectrometer with a resolution of $4 \mathrm{~cm}^{-1}$ in solid phase at room temperature. The Raman spectrum has been recorded on Renishaw Invia Raman microscope spectrophotometer in the $4000-100 \mathrm{~cm}^{-1}$ region. The excitation line at $785 \mathrm{~nm}$ has been taken from a diode laser. Its scan number is 100 , the resolution is $1 \mathrm{~cm}^{-1}$, and the sample is in solid phase.

\section{Computational details}

Density functional theory (DFT) is an approach to the electronic structure of atoms and molecules and states that all the groundstate properties of a system are function of the charge density. So, DFT calculations cannot be considered a pure $a b$ initio method. In DFT, the electron density is the basic variable, instead of the wave function. This reduces the computational burden of treating electron-electron interaction terms, which are treated explicitly as a functional of the density. The DFT approach combines the capacity to incorporate exchange-correlation effects of electrons with reasonable computational costs and high accuracy. The past few years has seen a rapid increase in the use of DFT methods in different types of applications, particularly since the introduction of accurate non-local corrections. In density functional theory, the exchange-correlation energy is the main issue among all of the approximations; therefore, the accuracy of DFT is depended directly by the approximate nature of the exchange-correlation energy functional. The DFT methods employed in the present paper are representative in aspect of the exchange-correlation energy and were commonly used in numerous theoretical studies [7-15].

The high parameterized, empirical exchange correlation functionals, M05-2X and M06-2X, developed by Zhao and Truhlar [16] have been shown to describe noncovalent interactions better than density functionals which are currently in common use.
However, these methods have yet to be fully benchmarked for the types of interactions important in biomolecules. M05-2X and M06-2X are claimed to capture "medium-range" electron correlation; however, the "long-range" electron correlation neglected by these functionals can also be important in the binding of noncovalent complex. Also, these methods have been used in numerous theoretical studies, recently [17-23].

Initial atomic coordinates can be generally taken from any database or experimental XRD results. We have used the experimental XRD data and GaussView software database to determine initial atomic coordinates and to optimize the input structure. After the optimization, we have used the most stable optimized structure for other theoretical analysis. In this study, initial atomic coordinates that taken from GaussView database [24] have given most stable structure after optimization. The molecular structure of the title molecule in the ground state (in gas phase) has been optimized by using DFT/B3LYP and M06-2X methods with $6-311++G(d, p)$ basis set level, and the calculated optimized structure has been used in the vibrational frequency calculations. The calculated harmonic vibrational frequencies have been scaled by 0.9614 (B3LYP) and 0.9489 (M06-2X) for 6-311++G(d,p) level, respectively $[24,25]$. The same scale factors were used for the entire spectra. The molecular geometry has not been limited, and all the calculations (vibrational wavenumbers, optimized geometric parameters and other molecular properties) have been performed using the Gauss View molecular visualization program [24] and the Gaussian 09W program package on a computing system [26]. Furthermore, the calculated vibrational frequencies have been clarified by means of the potential energy distribution (PED) analysis of all the fundamental vibration modes by using VEDA 4 program $[27,28]$. VEDA 4 program has been used in previous studies by many researchers $[10,15,23,29,30,14]$. All the vibrational assignments have been made at B3LYP/6-311++G(d,p) level for which the molecular structure is more stable. So, some assignments may correspond to its previous or next vibrational frequency value at M06-2X/6-311++G(d,p) level.

\section{Results and discussion}

\section{Geometric structure}

The single crystal X-ray structure analysis of the title compound $\left(\mathrm{C}_{11} \mathrm{H}_{6} \mathrm{~F}_{3} \mathrm{~N}_{3} \mathrm{O}\right)$ showed that its crystal possesses space group $\mathrm{C}_{2} / \mathrm{c}$ and belongs to monoclinic system with the following cell dimensions: $a=20.940 \AA, b=13.760 \AA, c=7.2852 \AA$ and, $\beta=96.369^{\circ}$ and $V=2086.2 \AA^{3}[6]$. The measured density of the molecule is $1.612 \mathrm{mg} / \mathrm{m}^{3}$. The theoretical and experimental structure parameters (bond lengths and bond angles) are shown in Table 1, in accordance with the atom numbering scheme (the optimized structure) in Fig. 1.

In the title compound, the 2-Trifluoromethyl-10H-benzo[4,5]imidazo[1,2-a]pyrimidin-4-one, $\left(\mathrm{C}_{11} \mathrm{H}_{6} \mathrm{~F}_{3} \mathrm{~N}_{3} \mathrm{O}\right)$, the three fused rings of the benzo[4,5]imidazo[1,2-a]pyrimidine unit are essentially coplanar; the maximum deviation from the mean plane being $0.096 \AA$. In the crystal, $\mathrm{N}-\mathrm{H} \cdots \mathrm{O}$ hydrogen bonds link the molecules into chains running along the $b$-axis direction [6]. The derivatives of benzopyrimidine are of great importance because of their remarkable biological properties. Some of them have shown good antineoplastic [31] and protein kinase inhibitor [32] activities. Also, heterocycles containing an imidazolone moiety exhibits various biological activities such as antibacterial and antifungal activities [33-35].

In the Ring $1, \mathrm{C}-\mathrm{F}$ bond lengths have been observed as experimentally at 1.301-1.328 $\AA$ [6], these bond lengths have found $1.348 \AA$ in B3LYP (three bond lengths are same) and changed from 
Table 1

Experimental and calculated geometric parameters of the title compound.

\begin{tabular}{|c|c|c|c|}
\hline \multirow{2}{*}{$\begin{array}{l}\text { Geometric parameters } \\
\text { Bond lengths }(\AA)\end{array}$} & \multirow[t]{2}{*}{ Experimental values [6] } & \multicolumn{2}{|l|}{ Calculated values } \\
\hline & & B3LYP/6-311++G(d,p) & M06-2X/6-311++G(d,p) \\
\hline $\mathrm{C} 1-\mathrm{C} 2$ & 1.365 & 1.367 & 1.361 \\
\hline $\mathrm{C} 1-\mathrm{C} 4$ & 1.412 & 1.444 & 1.446 \\
\hline $\mathrm{C} 1-\mathrm{H} 1$ & 0.930 & 1.079 & 1.079 \\
\hline $\mathrm{C} 2-\mathrm{N} 1$ & 1.349 & 1.358 & 1.356 \\
\hline $\mathrm{C} 2-\mathrm{C} 11$ & 1.498 & 1.519 & 1.514 \\
\hline $\mathrm{C} 3-\mathrm{N} 1$ & 1.311 & 1.303 & 1.299 \\
\hline $\mathrm{C} 3-\mathrm{N} 2$ & 1.381 & 1.380 & 1.374 \\
\hline $\mathrm{C} 3-\mathrm{N} 3$ & 1.339 & 1.365 & 1.360 \\
\hline $\mathrm{C} 4-\mathrm{N} 2$ & 1.407 & 1.430 & 1.420 \\
\hline $\mathrm{C} 4-\mathrm{O} 1$ & 1.228 & 1.217 & 1.209 \\
\hline $\mathrm{C} 5-\mathrm{C} 6$ & 1.380 & 1.389 & 1.386 \\
\hline $\mathrm{C} 5-\mathrm{C} 10$ & 1.393 & 1.406 & 1.400 \\
\hline $\mathrm{C} 5-\mathrm{N} 3$ & 1.385 & 1.392 & 1.390 \\
\hline $\mathrm{C} 6-\mathrm{C} 7$ & 1.380 & 1.394 & 1.390 \\
\hline $\mathrm{C} 6-\mathrm{H} 2$ & 0.930 & 1.083 & 1.082 \\
\hline $\mathrm{C} 7-\mathrm{C} 8$ & 1.392 & 1.400 & 1.397 \\
\hline $\mathrm{C} 7-\mathrm{H} 3$ & 0.930 & 1.083 & 1.083 \\
\hline $\mathrm{C} 8-\mathrm{C} 9$ & 1.378 & 1.394 & 1.391 \\
\hline $\mathrm{C} 8-\mathrm{H} 4$ & 0.930 & 1.083 & 1.082 \\
\hline C9-C10 & 1.386 & 1.389 & 1.387 \\
\hline $\mathrm{C} 9-\mathrm{H} 5$ & 0.930 & 1.080 & 1.080 \\
\hline $\mathrm{C} 10-\mathrm{N} 2$ & 1.406 & 1.406 & 1.403 \\
\hline N3-H6 & 0.860 & 1.007 & 1.007 \\
\hline $\mathrm{C} 11-\mathrm{F} 1$ & 1.328 & 1.348 & 1.335 \\
\hline $\mathrm{C} 11-\mathrm{F} 2$ & 1.313 & 1.348 & 1.336 \\
\hline $\mathrm{C} 11-\mathrm{F} 3$ & 1.301 & 1.348 & 1.337 \\
\hline$R^{2}$ & & 0.9793 & 0.9767 \\
\hline \multicolumn{4}{|l|}{ Bond angles $\left({ }^{\circ}\right)$} \\
\hline $\mathrm{C} 2-\mathrm{C} 1-\mathrm{C} 4$ & 120.6 & 120.7 & 120.1 \\
\hline $\mathrm{C} 2-\mathrm{C} 1-\mathrm{H} 1$ & 120.0 & 122.0 & 122.2 \\
\hline $\mathrm{C} 4-\mathrm{C} 1-\mathrm{H} 1$ & 120.0 & 117.2 & 117.6 \\
\hline $\mathrm{C} 1-\mathrm{C} 2-\mathrm{N} 1$ & 126.1 & 125.9 & 126.7 \\
\hline $\mathrm{C} 1-\mathrm{C} 2-\mathrm{C} 11$ & 120.6 & 120.7 & 120.4 \\
\hline $\mathrm{N} 1-\mathrm{C} 2-\mathrm{C} 11$ & 113.3 & 113.2 & 112.8 \\
\hline $\mathrm{N} 1-\mathrm{C} 3-\mathrm{N} 2$ & 125.6 & 126.0 & 126.0 \\
\hline $\mathrm{N} 1-\mathrm{C} 3-\mathrm{N} 3$ & 126.8 & 126.5 & 126.6 \\
\hline $\mathrm{N} 2-\mathrm{C} 3-\mathrm{N} 3$ & 107.5 & 107.3 & 107.3 \\
\hline $\mathrm{C} 1-\mathrm{C} 4-\mathrm{N} 2$ & 112.8 & 111.4 & 111.3 \\
\hline $\mathrm{C} 1-\mathrm{C} 4-\mathrm{O} 1$ & 128.3 & 128.1 & 128.4 \\
\hline $\mathrm{N} 2-\mathrm{C} 4-\mathrm{O} 1$ & 118.9 & 120.3 & 120.2 \\
\hline $\mathrm{C} 6-\mathrm{C} 5-\mathrm{C} 10$ & 121.5 & 121.3 & 121.3 \\
\hline $\mathrm{C} 6-\mathrm{C} 5-\mathrm{N} 3$ & 131.0 & 131.5 & 131.5 \\
\hline $\mathrm{C} 10-\mathrm{C} 5-\mathrm{N} 3$ & 107.5 & 107.0 & 107.0 \\
\hline $\mathrm{C} 5-\mathrm{C} 6-\mathrm{C} 7$ & 116.7 & 117.0 & 116.9 \\
\hline $\mathrm{C} 5-\mathrm{C} 6-\mathrm{H} 2$ & 122.0 & 121.5 & 121.5 \\
\hline $\mathrm{C} 7-\mathrm{C} 6-\mathrm{H} 2$ & 122.0 & 121.3 & 121.5 \\
\hline $\mathrm{C} 6-\mathrm{C} 7-\mathrm{C} 8$ & 121.8 & 121.5 & 121.6 \\
\hline $\mathrm{C} 6-\mathrm{C} 7-\mathrm{H} 3$ & 119.0 & 119.0 & 119.0 \\
\hline $\mathrm{C} 8-\mathrm{C} 7-\mathrm{H} 3$ & 119.0 & 119.4 & 119.3 \\
\hline $\mathrm{C} 7-\mathrm{C} 8-\mathrm{C} 9$ & 121.8 & 121.5 & 121.5 \\
\hline $\mathrm{C} 7-\mathrm{C} 8-\mathrm{H} 4$ & 119.0 & 119.3 & 119.3 \\
\hline $\mathrm{C} 9-\mathrm{C} 8-\mathrm{H} 4$ & 119.0 & 119.1 & 119.1 \\
\hline $\mathrm{C} 8-\mathrm{C} 9-\mathrm{C} 10$ & 116.4 & 116.8 & 116.5 \\
\hline $\mathrm{C} 8-\mathrm{C} 9-\mathrm{H} 5$ & 122.0 & 122.6 & 122.8 \\
\hline $\mathrm{C} 10-\mathrm{C} 9-\mathrm{H} 5$ & 122.0 & 120.5 & 120.5 \\
\hline $\mathrm{C} 5-\mathrm{C} 10-\mathrm{C} 9$ & 121.9 & 121.7 & 121.9 \\
\hline $\mathrm{C} 5-\mathrm{C} 10-\mathrm{N} 2$ & 105.8 & 106.4 & 106.3 \\
\hline $\mathrm{C} 9-\mathrm{C} 10-\mathrm{N} 2$ & 132.3 & 131.8 & 131.7 \\
\hline $\mathrm{C} 2-\mathrm{N} 1-\mathrm{C} 3$ & 113.4 & 113.9 & 113.3 \\
\hline $\mathrm{C} 3-\mathrm{N} 2-\mathrm{C} 4$ & 121.4 & 121.8 & 122.4 \\
\hline $\mathrm{C} 3-\mathrm{N} 2-\mathrm{C} 10$ & 108.9 & 109.1 & 109.3 \\
\hline $\mathrm{C} 4-\mathrm{N} 2-\mathrm{C} 10$ & 129.7 & 128.9 & 128.2 \\
\hline $\mathrm{C} 3-\mathrm{N} 3-\mathrm{C} 5$ & 110.2 & 109.9 & 109.8 \\
\hline $\mathrm{C} 3-\mathrm{N} 3-\mathrm{H} 6$ & 125.0 & 122.4 & 122.3 \\
\hline $\mathrm{C} 5-\mathrm{N} 3-\mathrm{H} 6$ & 125.0 & 127.6 & 127.7 \\
\hline $\mathrm{C} 2-\mathrm{C} 11-\mathrm{F} 2$ & 112.3 & 111.2 & 111.1 \\
\hline $\mathrm{C} 2-\mathrm{C} 11-\mathrm{F} 1$ & 112.8 & 111.2 & 110.8 \\
\hline $\mathrm{C} 2-\mathrm{C} 11-\mathrm{F} 3$ & 113.7 & 112.0 & 111.9 \\
\hline $\mathrm{F} 2-\mathrm{C} 11-\mathrm{F} 1$ & 103.8 & 107.3 & 107.6 \\
\hline $\mathrm{F} 2-\mathrm{C} 11-\mathrm{F} 3$ & 106.7 & 107.3 & 107.5 \\
\hline $\mathrm{F} 1-\mathrm{C} 11-\mathrm{F} 3$ & 106.9 & 107.3 & 107.5 \\
\hline$R^{2}$ & & 0.9747 & 0.9713 \\
\hline
\end{tabular}




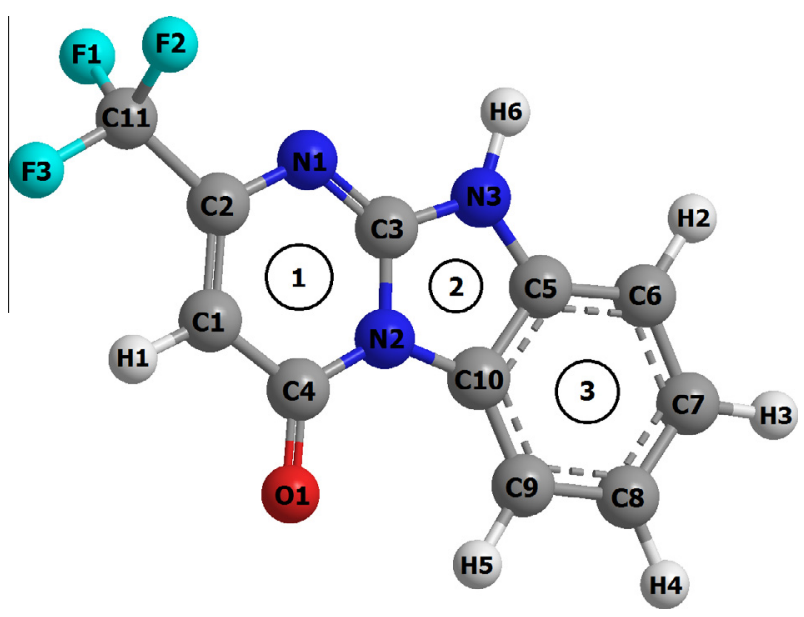

Fig. 1. The optimized molecular structure of the title compound.

1.335 to $1.337 \AA$ in M06-2X methods. These bonds have been reported from 1.3385 to $1.3493 \AA$ in B3LYP/6-311G** and from 1.299 to $1.329 \AA$ in experimentally for (2-trifluoromethyl-5,6, 7,8-tetrahydrobenzo[4,5]-thieno[2,3-d]pyrimidin-4-yl)hydrazone monohydrate [36]. Similarly, for 2-amino-4-hydroxy6-trifluoromethylpyrimidine $\mathrm{C}-\mathrm{F}$ bonds have been calculated from 1.34608 to $1.35258 \AA$ in $\mathrm{B} 3 \mathrm{LYP} / 6-311+\mathrm{G}^{* *}$ method [37]. In pyridine ring $\mathrm{N} 1-\mathrm{C} 2, \mathrm{~N} 1-\mathrm{C} 3, \mathrm{C} 3-\mathrm{N} 2, \mathrm{~N} 2-\mathrm{C} 4, \mathrm{C} 4-\mathrm{C} 1$ and $\mathrm{C} 1-\mathrm{C} 2$ bond lengths have been observed $1.349,1.311,1.381,1.407,1.412$ and 1.365 $\AA \AA$, respectively in X-ray study [6]. These bond lengths have been calculated at 1.358/1.356, 1.303/1.299, 1.380/1.374, 1.430/1.420, $1.444 / 1.446$ and $1.367 / 1.361 \AA \AA$ in B3LYP/M06-2X methods. These bond lengths have been calculated 1.316, 1.346, 1.344, 1.328, 1.383 and $1.408 \AA$, respectively in B3LYP/6-311+G** method [37]. For N1-C2 and N2-C4 bond lengths have been calculated 1.307/ 1.322 and $1.317 / 1.334$ in HF/B3LYP methods with $6-311++\mathrm{G}(\mathrm{d}, \mathrm{p})$ basis set in 2,4-dichloropyrimidine [38]. For 1,2-dihydropyrazolo(4,3-E)pyrimidin-4-one [39] C3-N2, C4-C1 and C1-C2 bond lengths have been calculated 1.26/1.301, 1.336/1.401 and 1.3511/ $1.442 \AA$, respectively, in HF/DFT methods with $6-31 \mathrm{G}(\mathrm{d}, \mathrm{p})$ basis set. In this ring, $\mathrm{C} 4-\mathrm{O} 1$ bond length have been reported as experimentally $1.228 \AA$ [6] and calculated $1.217 / 1.209 \AA$ in B3LYP/M06$2 \mathrm{X}$ methods with $6-311++\mathrm{G}(\mathrm{d}, \mathrm{p})$. This bond length have been calculated 1.124/1.4307 $\AA$ in HF/DFT methods with 6-31G(d,p) basis set for [1,2-dihydropyrazolo (4,3-E)pyrimidin-4-one [39].

In ring $2, \mathrm{C} 3-\mathrm{N} 3, \mathrm{~N} 3-\mathrm{C}, \mathrm{C} 3-\mathrm{N} 2$ and $\mathrm{N} 2-\mathrm{C} 10$ bond lengths have been reported [6] as $1.339,1.385,1.381$ and $1.406 \AA$, respectively. In this study these bond lengths have been calculated 1.365/ $1.360,1.392 / 1.390,1.380 / 1.374$ and $1.406 / 1.403 \AA$, respectively in B3LYP/M06-2X methods. For 2,6-bis(1-benzyl-1H-benzo[d]imidazol-2-yl)pyrimidine [40], these bond lengths were calculated $1.317,1.378,1.388$ and $1.385 \AA$, respectively. These bond lengths have been calculated for 2-(thiophene-2-yl)-1H-benzo[d]imidazole(tautomer 1) [41] 1.315, 1.382, 1.383 and $1.384 \AA$, respectively by using B3LYP/6-311++G(d,p). Additionally, in this study C5-C10 bond length has been calculated 1.406/1.400 $\AA$ in B3LYP/M06-2X methods, and this bond length for 2-(thiophene-2-yl)-1Hbenzo[d]imidazole(tautomer 1) [41] has been reported as $1.415 \AA$.

C3-N2-C10 bond angle was calculated $109.1 / 109.3^{\circ}$ in B3LYP/ M06-2X methods and observed [6] experimentally as $108.9^{\circ}$. This angle was calculated $105.97^{\circ}$ for 2,6-bis(1-benzyl-1H-benzo[d]imidazol-2-yl)pyrimidine [40]. C10-C5-C6 and N2-C3-N3 bond angles have been reported as $121.5^{\circ}$ and $107.5^{\circ}$ experimentally [6] and calculated $121.3 / 121.3^{\circ}$ and $107.3 / 107.3^{\circ}$ in B3LYP/ M06-2X methods. These bond angles have been calculated $120.9^{\circ}, 121.1^{\circ}, 121.1^{\circ}, 121.4^{\circ}$ for $\mathrm{C} 10-\mathrm{C} 5-\mathrm{C} 6$ angle by using different theoretical methods and $110.5^{\circ} 109.9^{\circ}, 111.2^{\circ}$ and $110.3^{\circ}$ for N2-C3-N3 angles with same methods for 2-(1H-imidazo [4,5-f][1,10]phenanthrolin-2yl)phenol [42]. As we can be seen in Table 1 that all of the other distances and angles agree well with the literature. To make comparison with experimental results, we present linear correlation coefficients $\left(R^{2}\right)$ for linear regression analysis of theoretical and experimental bond lengths and angles. These values are 0.9793 and 0.9767 for bond lengths, and 0.9747 and 0.9713 for bond angles with B3LYP and M06-2X. These coefficients can be seen in the last line of Table 1 . From these values it can easily be concluded that the geometric parameters calculated with the B3LYP method is much closer to the experimental data.

The largest differences between the calculated (B3LYP/ $6-311++G(d, p))$ and experimental geometries are: $0.032 \AA$ for the C1 $-\mathrm{C} 4$ bond, $0.021 \AA$ for the $\mathrm{C} 2-\mathrm{C} 11$ bond, $0.026 \AA$ for the $\mathrm{C} 3-\mathrm{N} 3$ bond, $0.023 \AA$ for the $\mathrm{C} 4-\mathrm{N} 2$ bond, $0.147 \AA$ for the N3-H6 bond, $0.047 \AA$ for the $\mathrm{C} 11-\mathrm{F} 3$ bond; $1.4^{\circ}$ for the $\mathrm{C} 1-\mathrm{C} 4-\mathrm{N} 2$ and $\mathrm{N} 2-\mathrm{C} 4-\mathrm{O} 1$ bond angles, $1.5^{\circ}$ for the $\mathrm{C} 10-\mathrm{C} 9-\mathrm{H} 5,2.6^{\circ}$ for the $\mathrm{C} 3-\mathrm{N} 3-\mathrm{H} 6$ and $\mathrm{C} 5-\mathrm{N} 3-\mathrm{H} 6,1.7^{\circ}$ for the $\mathrm{C} 2-\mathrm{C} 11-\mathrm{F} 3$ and $3.5^{\circ}$ for the $\mathrm{F} 2-\mathrm{C} 11-\mathrm{F} 1$ bond angles.

\section{Vibrational analysis}

The experimental FT-IR and Laser-Raman spectra of the title compound are compared with the selected theoretical spectra in Figs. 2 and 3, respectively. The scaled calculated harmonic vibrational frequencies at both B3LYP and M06-2X levels, observed vibrational frequencies, and detailed PED assignments are tabulated in Table 2. The harmonic frequencies are calculated for gaseous phase of the isolated title molecule although the experimental ones are obtained for its solid phase. The molecule is interconnected by intermolecular $\mathrm{N}-\mathrm{H} \cdots \mathrm{O}$ hydrogen bonds in solid phase [6]. Consequently, there is slightly disagreement between the observed (experimental) and the calculated frequencies in some modes. So, in order to introduce detailed vibrational assignments of the title molecule, the PED analysis has been carried out. All the calculated modes are numbered from the largest to the smallest frequency within each fundamental wave number.

\section{Ring 1 vibrations}

In heterocyclic organic molecules, $\mathrm{C}-\mathrm{H}$ stretching modes are commonly observed in the region $3500-3000 \mathrm{~cm}^{-1}$. This is the characteristic region for the ready identification of $\mathrm{C}-\mathrm{H}$ stretching vibration [43]. In this region, the bands are not affected appreciably by nature of the substituents. For 2-amino-4-hydroxy 6-trifluoromethylpyrimidine [37] the band was observed at $3181 \mathrm{~cm}^{-1}$. In the present investigation, the band observed at $3113 \mathrm{~cm}^{-1}$ in FT-IR spectrum and this mode was not observed in Laser-Raman spectrum. This mode was calculated at 3116(B3LYP)/3091(M06$2 \mathrm{X}) \mathrm{cm}^{-1}$. The $\mathrm{C}-\mathrm{H}$ bending vibrations $(\delta \mathrm{HCC})$ are expected to interact a little around $1300-1600 \mathrm{~cm}^{-1}$ with ring vibrations $[37,43]$. In this study, $\mathrm{C}-\mathrm{H}$ in plane bending vibrations have been observed at 1353(IR)/1373(Ra) and 1246(IR)/1253(Ra) $\mathrm{cm}^{-1}$ and calculated at 1345(B3LYP)/1341(M06-2X) and 1232(B3LYP)/ 1247(M06-2X), respectively. The band at $806 \mathrm{~cm}^{-1}$ as associated with $\mathrm{C}-\mathrm{H}$ out of plane bending mode [37]. In this study, $\mathrm{CH}$ out of plane bending modes have been observed at $821(\mathrm{IR}) / 861(\mathrm{Ra})$ and $737(\mathrm{IR}) / 728(\mathrm{Ra}) \mathrm{cm}^{-1}$ and calculated at $822(\mathrm{~B} 3 \mathrm{LYP}) /$ 814(M06-2X) and 742(B3LYP)/745(M06-2X), respectively.

The $\mathrm{C}=\mathrm{O}$ stretch of carboxylic acids is identical to the $\mathrm{C}=\mathrm{O}$ stretch in ketones, which is expected in the region 1740$1660 \mathrm{~cm}^{-1}$ [44]. This band is reasonably easy to be recognized due to its high intensity. For 9-[(2-hydroxyethoxy)methyl] guanine [45] the band were observed at 1633 and $1632 \mathrm{~cm}^{-1}$ in FT-IR and FT-Raman spectra. In this study $\mathrm{C}=\mathrm{O}$ stretching modes have 


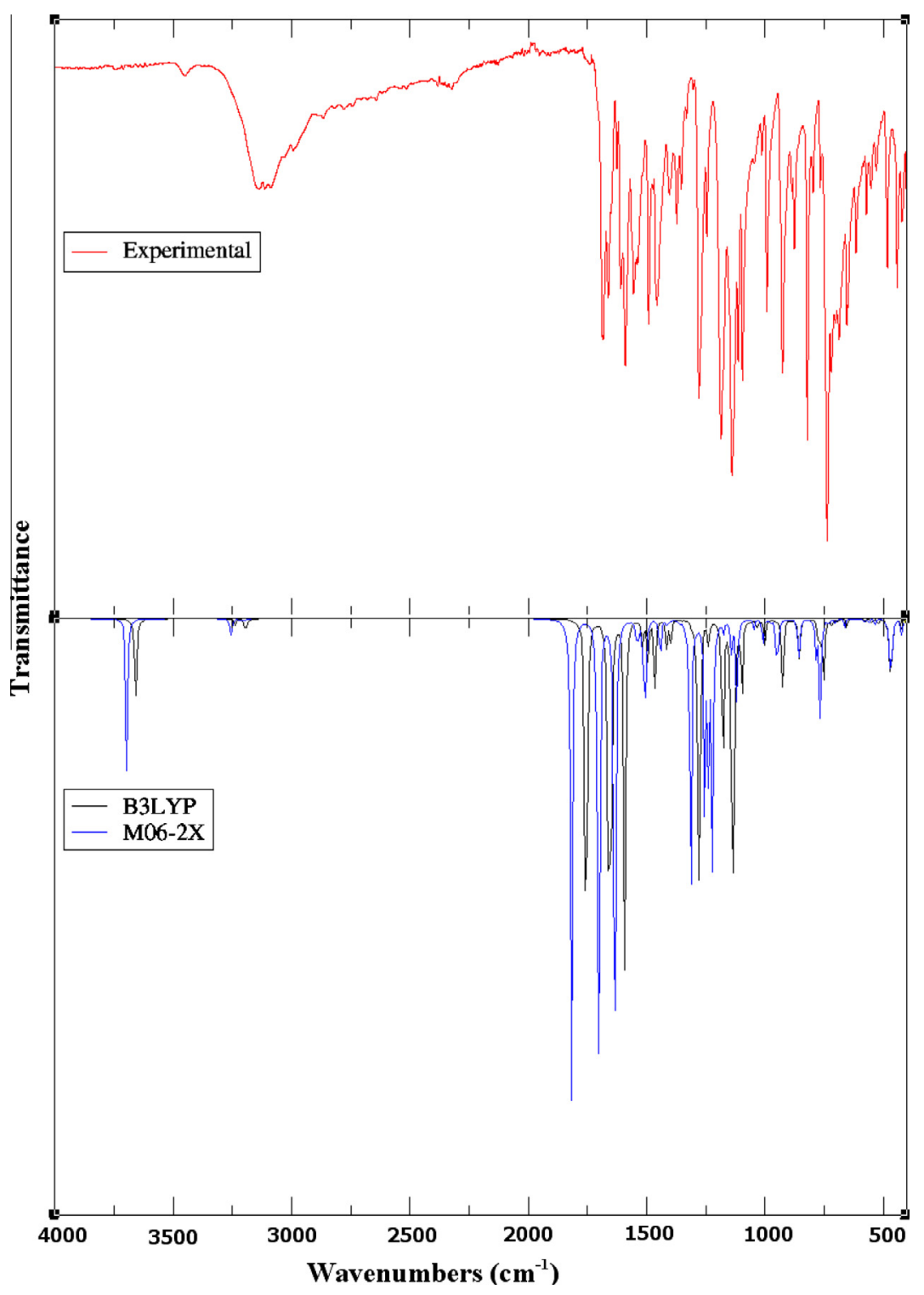

Fig. 2. Comparison of observed and calculated infrared spectra of the title compound.

been observed at 1684(IR)/1674 (Raman) and calculated at 1689(B3LYP)/1725(M06-2X) $\mathrm{cm}^{-1}$. In plane bending $\delta$ OCC (01-C4-C1) modes have been observed at 615(IR)/661(Ra), $403 \mathrm{~cm}^{-1}$ in FT-IR and $345 \mathrm{~cm}^{-1}$ in Laser-Raman spectra and calculated at 630(B3LYP)/630(M06-2X), 398(B3LYP)/396(M06-2X) and 331(B3LYP)/334(M06-2X), respectively. Out of plane $\gamma$ ONCC (O1-N2-C4-C1) modes have been observed 821(IR)/861(Ra), 737(IR)/728(Ra), 687(IR)/694(Ra) and 655(IR)/661(Ra) $\mathrm{cm}^{-1}$ and calculated in v36, v37, v42 and v44 modes.

Pyrimidines absorb strongly in the region $1600-1500 \mathrm{~cm}^{-1}$ due to the $\mathrm{C}=\mathrm{C}(\mathrm{C} 2=\mathrm{C} 1)$ and $\mathrm{C}=\mathrm{N}(\mathrm{N} 1=\mathrm{C} 3)$ ring stretching vibrations $[46,47] . C 2=C 1$ modes have been observed at $1609(\mathrm{IR}) / 1612(\mathrm{Ra})$, $1590(\mathrm{IR}) / 1588(\mathrm{Ra})$ and $1556(\mathrm{IR}) / 1559(\mathrm{Ra}) \mathrm{cm}^{-1}$ and $\mathrm{N} 1=\mathrm{C} 3$ stretching modes have been observed at 1609(IR)/1612(Ra) and $1590(\mathrm{IR}) / 1588(\mathrm{Ra}) \mathrm{cm}^{-1}$. These stretching modes are agreed with theoretical values and this agreement can be seen in Table 2. The identification of $\mathrm{C}=\mathrm{N}$ vibrations is a difficult task, since the mixing of vibrations is possible in this region. The unconjucated $\mathrm{C}=\mathrm{N}$ linkage in the amine gives medium to weak bands near 1250$1020 \mathrm{~cm}^{-1}$ [47]. $\mathrm{C}=\mathrm{N}$ modes have been observed at $1404(\mathrm{IR}) /$
1411(Ra), 1373(IR)/1373(Ra), 1139(IR)/1148(Ra) and 1047(IR)/ 1029 (Ra) $\mathrm{cm}^{-1}$ and these modes agreed with the theoretical calculations (v14, v15, v24 and v28).

Usually symmetric and antisymmetric $\mathrm{CF}_{3}$ vibrations are in the ranges $1270-1235$ and $1226-1200 \mathrm{~cm}^{-1}$, respectively $[48,49]$. In this study, there are nine stretching $\mathrm{CF}_{3}$ modes. These are four symmetric and five asymmetric modes. Symmetric modes were observed at 1246(IR)/1253(Ra), 890(IR)/876(Ra), 721(IR)/728 (Ra) and 687(IR)/694(Ra) $\mathrm{cm}^{-1}$ and asymmetric stretching modes were observed at 1139(IR)/1148(Ra), 1113(IR)/1091(Ra), 1095 (IR)/1091(Ra), 530(Ra) and 506(Ra) $\mathrm{cm}^{-1}$. These modes agree with theoretical values and this agreement can be seen in Table 2. For 2-amino4-hydroxy6-trifluoromethylpyrimidine [37], these modes are compatible with our modes values. The other wave numbers of the trifluoromethyl group such as symmetric modes (v19, v40, v41 and v43), asymmetric modes (v25), out of plane modes $\gamma$ FCFC (v26, v49, v50, v56, v57, v60, v62 and v63), twisting modes (v50, v51, v54, v55, v56, v57, v59) and rocking modes (v49) are also assigned and presented in Table 2 . These assignments are substantiated by the reported literatures of similar kind of molecules. 


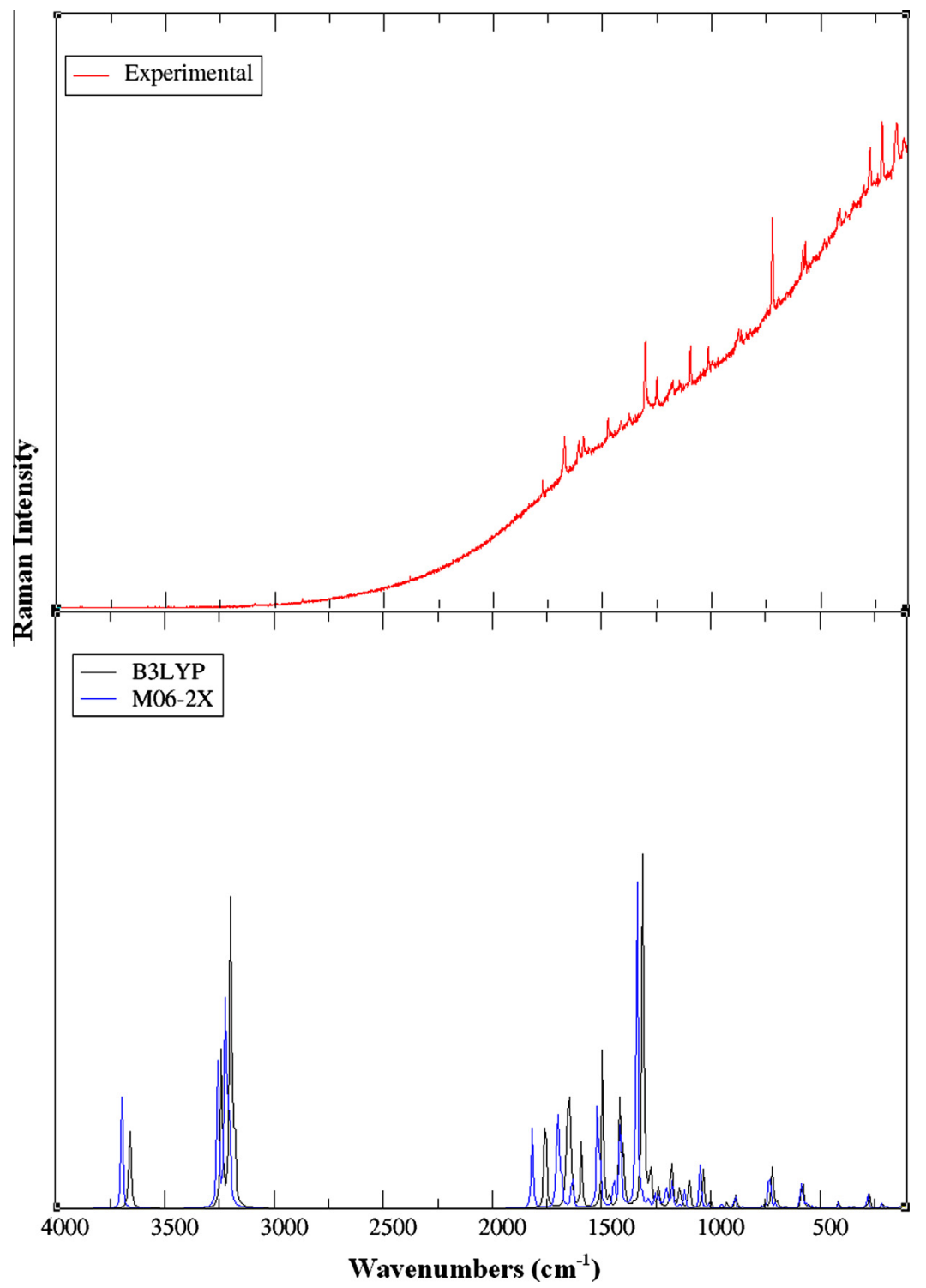

Fig. 3. Comparison of observed and calculated Raman spectra of the title compound.

\section{Ring 2 vibrations}

It has been observed that the presence of $\mathrm{N}-\mathrm{H}$ in various molecules may be correlated with a constant occurrence of absorption bands whose positions are slightly altered from one compound to another; this is because the atomic group vibrates independently of the other groups in the molecule and has its own frequency. In all the heterocyclic compounds, the $\mathrm{N}-\mathrm{H}$ stretching vibrations occur in the region $3500-3000 \mathrm{~cm}^{-1}$ [50]. In this study $\mathrm{N}-\mathrm{H}(\mathrm{N} 3-\mathrm{H} 6$ in the ring 2) stretching mode was observed at $3456 \mathrm{~cm}^{-1}$ in FT-IR spectrum, but this mode was not observed in Laser-Raman spectrum, which is further supported by the PED contribution of $100 \%$. This mode was calculated at 3518(B3LYP)/3507(M06-2X) $\mathrm{cm}^{-1}$ with 6$311++\mathrm{G}(\mathrm{d}, \mathrm{p})$ basis set. By Arivazhagan et al. [51], N-H stretching vibrations have been found at $3258,3210,3116 \mathrm{~cm}^{-1}$ in IR and $3132 \mathrm{~cm}^{-1}$ in Raman spectrum for xanthenes. The in-plane bending $\delta$ HNC modes have been observed at 1373(IR)/1373(Ra), 1329(IR)/ 1296(Ra), $1246(\mathrm{IR}) / 1253(\mathrm{Ra})$ and $1185(\mathrm{IR}) / 1182(\mathrm{Ra}) \mathrm{cm}^{-1}$ and calculated at 1361(B3LYP)/1370(M06-2X), 1300(B3LYP)/ 1288(M06-2X), 1224(B3LYP)/1219(M06-2X) and 1191(B3LYP)/ 1191(M06-2X), respectively. The out of plane modes ( $\tau \mathrm{HNCN}$ ) have been observed at 441(IR)/422(Ra) and 403(IR)/407(Ra) $\mathrm{cm}^{-1}$, and calculated at 451(B3LYP)/445(M06-2X) and 407(B3LYP)/402 (M06-2X) $\mathrm{cm}^{-1}$, respectively. The in-plane and out of plane bending vibrations of $\mathrm{N}-\mathrm{H}$ group are also supported by the literature [51,52].

In ring 2, other related modes are $v N C$ stretching modes (v15:N2-C3, v21:N3-C5 and v23:N3-C3), bending modes $\delta C N C$ (v16:C3-N3-C5 and v18:N2-C3-N3) and $8 N C N$ (v63:N2C3-N3), torque modes $\tau$ CCNC (v39: $110-\mathrm{C} 5-\mathrm{N} 3-\mathrm{C} 3)$ and $\tau \mathrm{CNCN}$ (v:64:C2-N1-C3-N3) and out of modes $\gamma$ NNNC (v44:N1-N2N3- C3). These modes of ring 2 are also supported by the literature $[51,52]$.

\section{Ring 3 vibrations}

Aromatic compounds commonly exhibit multiple weak bands in the region $3100-3000 \mathrm{~cm}^{-1}$ due to aromatic $\mathrm{C}-\mathrm{H}$ stretching vibrations which is the characteristic region for ready identification of this structure [53-56]. In this region, the bands are not affected appreciably by nature of the substituent. In this study, there are two symmetric and two asymmetric stretching modes. The symmetric stretching mode was observed at $3113 \mathrm{~cm}^{-1}$ in FT-IR spectrum. The asymmetric mode was observed $3086 \mathrm{~cm}^{-1}$ in 
Table 2

Observed and calculated vibrational frequencies of the title compound with $6-311++G(d, p)$.

\begin{tabular}{|c|c|c|c|c|c|}
\hline \multirow[t]{2}{*}{$\begin{array}{l}\text { Vibration } \\
\text { no. }\end{array}$} & \multirow[t]{2}{*}{ Assignments } & \multicolumn{2}{|c|}{ Observed frequencies } & \multicolumn{2}{|c|}{$\begin{array}{l}\text { Calculated } \\
\text { frequencies in } \mathrm{cm}^{-1}\end{array}$} \\
\hline & & FT-IR & Laser-Ra. & B3LYP & M06-2X \\
\hline$v_{1}$ & $\mathrm{vNH}(100)$ in the $\mathrm{N} 3-\mathrm{H} 6$ (ring 2) & 3456 & & 3518 & 3507 \\
\hline$v_{2}$ & $v \mathrm{CH}(100)$ in the $\mathrm{C} 1-\mathrm{H} 1$ (ring 1 ) & 3113 & & 3116 & 3091 \\
\hline$v_{3}$ & $\mathrm{vCH}(98)$ in the ring 3 & 3113 & & 3112 & 3088 \\
\hline$v_{4}$ & $v \mathrm{CH}(94)$ in the ring 3 & 3086 & & 3076 & 3057 \\
\hline$v_{5}$ & $v \mathrm{CH}(94)$ in the ring 3 & 3086 & & 3067 & 3047 \\
\hline$v_{6}$ & $\mathrm{vCH}(95)$ in the ring 3 & 3086 & & 3055 & 3037 \\
\hline$v_{7}$ & $\mathrm{vOC}(64)$ in the $\mathrm{O} 1-\mathrm{C} 4+\delta \mathrm{CNC}(14)$ in the $\mathrm{C} 4-\mathrm{N} 2-\mathrm{C} 3$ & 1684 & 1674 & 1689 & 1725 \\
\hline$v_{8}$ & $\mathrm{vCC}(34)$ in the $\mathrm{C} 5-\mathrm{C} 6, \mathrm{C} 8-\mathrm{C} 9, \mathrm{C} 1-\mathrm{C} 2+\mathrm{vNC}(15)$ in the $\mathrm{N} 1-\mathrm{C} 3$ & 1609 & 1612 & 1598 & 1618 \\
\hline$v_{9}$ & $v N C(27)$ in the $\mathrm{N} 1-\mathrm{C} 3+v \mathrm{CC}(22)$ in the $\mathrm{C} 5-\mathrm{C} 6, \mathrm{C} 2-\mathrm{C} 1$ & 1590 & 1588 & 1588 & 1611 \\
\hline$v_{10}$ & $v \mathrm{CC}(54)$ in the $\mathrm{C} 7-\mathrm{C} 8+\delta \mathrm{CCC}(12)$ in the $\mathrm{C} 5-\mathrm{C} 6-\mathrm{C} 7$ & 1590 & 1588 & 1576 & 1597 \\
\hline$v_{11}$ & $\mathrm{vCC}(57)$ in the $\mathrm{C} 1-\mathrm{C} 2$ & 1556 & 1559 & 1531 & 1552 \\
\hline$v_{12}$ & $\delta \mathrm{HCC}(33)$ in the ring $3+v \mathrm{CC}(25)$ in the $\mathrm{C} 8-\mathrm{C} 9$ & 1456 & 1478 & 1459 & 1461 \\
\hline$v_{13}$ & $\delta \mathrm{HCC}(36)$ in the ring $3+\delta \mathrm{CCC}(27)$ in the $\mathrm{C} 7-\mathrm{C} 8-\mathrm{C} 9$ & 1456 & 1478 & 1438 & 1440 \\
\hline$v_{14}$ & $\mathrm{vNC}(29)$ in the $\mathrm{N} 1-\mathrm{C} 2+\delta \mathrm{CCN}(15)$ in the $\mathrm{C} 1-\mathrm{C} 2-\mathrm{N} 1$ & 1404 & 1411 & 1409 & 1430 \\
\hline$v_{15}$ & $\mathrm{vNC}(34)$ in the $\mathrm{N} 2-\mathrm{C} 3+\mathrm{vCC}(14)$ in the $\mathrm{C} 7-\mathrm{C} 8+\delta \mathrm{HNC}(13)$ in the $\mathrm{H} 6-\mathrm{N} 3-\mathrm{C} 3$ & 1373 & 1373 & 1361 & 1370 \\
\hline$v_{16}$ & $\mathrm{vCC}(11)$ in the $\mathrm{C} 7-\mathrm{C} 8+\delta \mathrm{HCC}(11)$ in the ring 1 and ring $3+\delta \mathrm{CNC}(10)$ in the $\mathrm{C} 3-\mathrm{N} 3-\mathrm{C} 5$ & 1353 & 1373 & 1345 & 1341 \\
\hline$v_{17}$ & $\delta \mathrm{HCC}(25)$ in the ring $3+\delta \mathrm{HNC}(11)$ in the $\mathrm{H} 6-\mathrm{N} 3-\mathrm{C} 3+\mathrm{vCC}(11)$ in the $\mathrm{C} 9-\mathrm{C} 10$ & 1329 & 1296 & 1300 & 1288 \\
\hline$v_{18}$ & $\mathrm{vCC}(14)$ in the $\mathrm{C} 8-\mathrm{C} 9+\delta \mathrm{NCN}(13)$ in the $\mathrm{N} 2-\mathrm{C} 3-\mathrm{N} 3$ & 1279 & 1253 & 1259 & 1269 \\
\hline$v_{19}$ & $\delta \mathrm{HCC}(41)$ in the ring $1+\mathrm{vCC}(18)$ in the $\mathrm{C} 2-\mathrm{C} 11+\mathrm{vFC}(13)$ in the $\mathrm{F} 2-\mathrm{C} 11+\delta \mathrm{FCF}(11)$ in the $\mathrm{F} 1-\mathrm{C} 11-\mathrm{F} 3$ & 1246 & 1253 & 1232 & 1247 \\
\hline$v_{20}$ & $\delta \mathrm{HNC}(17)$ in the $\mathrm{H} 6-\mathrm{N} 3-\mathrm{C} 3+\delta \mathrm{HCC}(12)$ in the ring 3 & 1246 & 1253 & 1224 & 1219 \\
\hline$v_{21}$ & $\mathrm{vNC}(27)$ in the $\mathrm{N} 3-\mathrm{C} 5+\delta \mathrm{HNC}(15)$ in the $\mathrm{H} 6-\mathrm{N} 3-\mathrm{C} 5$ & 1185 & 1182 & 1191 & 1191 \\
\hline$v_{22}$ & $\delta \mathrm{HCC}(47)$ in the ring $3+v \mathrm{CC}(10)$ in the $\mathrm{C} 1-\mathrm{C} 4$ & 1139 & 1148 & 1137 & 1176 \\
\hline$v_{23}$ & $\mathrm{vFC}(19)$ in the $\mathrm{F}-\mathrm{C} 11+\delta \mathrm{HCC}(12)$ in the ring $3+\mathrm{vNC}(10)$ in the $\mathrm{N} 3-\mathrm{C} 3$ & 1139 & 1148 & 1134 & 1160 \\
\hline$v_{24}$ & $\mathrm{vNC}(27)$ in the $\mathrm{N} 2-\mathrm{C} 4+\delta \mathrm{HCC}(25)$ in the ring 1 and ring 3 & 1139 & 1148 & 1131 & 1142 \\
\hline$v_{25}$ & $\delta \mathrm{FCF}(48)$ in the $\mathrm{F}-\mathrm{C} 11-\mathrm{F}+\mathrm{vFC}(45)$ in the $\mathrm{F}-\mathrm{C} 11$ & 1113 & 1091 & 1098 & 1119 \\
\hline$v_{26}$ & $\mathrm{vFC}(79)$ in the $\mathrm{F}-\mathrm{C} 11+\gamma \mathrm{FCFC}(14)$ in the $\mathrm{F} 1-\mathrm{C} 11-\mathrm{F} 3-\mathrm{C} 2$ & 1095 & 1091 & 1089 & 1115 \\
\hline$v_{27}$ & $\delta \mathrm{HCC}(36)$ in the ring 3 and ring 1 & 1095 & 1091 & 1088 & 1084 \\
\hline$v_{28}$ & $\mathrm{vNC}(35)$ in the $\mathrm{N} 1-\mathrm{C} 2+\delta \mathrm{HCC}(10)$ in the ring 1 & 1047 & 1029 & 1056 & 1062 \\
\hline$v_{29}$ & $\mathrm{vCC}(37)$ in the $\mathrm{C} 7-\mathrm{C} 8+\delta \mathrm{HCC}(15)$ in the ring 3 & 993 & 1029 & 994 & 995 \\
\hline$v_{30}$ & $\begin{array}{l}\delta C C N(17) \text { in the } \mathrm{C} 1-\mathrm{C} 4-\mathrm{N} 2+\delta \mathrm{CCC}(13) \text { in the } \mathrm{C} 8-\mathrm{C} 9-\mathrm{C} 10+\delta \mathrm{NCN}(12) \text { in the } \mathrm{N} 1-\mathrm{C} 3-\mathrm{N} 2+\mathrm{vNC}(12) \text { in } \\
\text { the } \mathrm{N} 1-\mathrm{C} 2\end{array}$ & 993 & 971 & 963 & 959 \\
\hline$v_{31}$ & $\tau \mathrm{HCCC}(71)$ in the ring 3 out of $\mathrm{H}+\tau \mathrm{CCNC}(12)$ in the $\mathrm{C} 6-\mathrm{C} 5-\mathrm{N} 3-\mathrm{C} 3$ & 926 & 971 & 953 & 958 \\
\hline$v_{32}$ & $\tau \mathrm{HCCC}(73)$ in the RiNG 3 out of $\mathrm{H}$ & 926 & 971 & 918 & 927 \\
\hline$v_{33}$ & $v \mathrm{FC}(22)$ in the $\mathrm{F}-\mathrm{C} 11+\delta \mathrm{CNC}(21)$ in the $\mathrm{C} 2-\mathrm{N} 1-\mathrm{C} 3$ & 890 & 876 & 890 & 900 \\
\hline$v_{34}$ & $\delta \mathrm{CCC}(42)$ in the $\mathrm{C} 7-\mathrm{C} 8-\mathrm{C} 9$ & 876 & 861 & 851 & 845 \\
\hline$v_{35}$ & $\tau \mathrm{HCCC}(76)$ in the ring 3 out of $\mathrm{H}$ & 821 & 861 & 833 & 840 \\
\hline$v_{36}$ & $\tau \mathrm{HCCC}(75)$ in the ring 1 out of $\mathrm{H}+\gamma \mathrm{ONCC}(13)$ in the $01-\mathrm{N} 2 \mathrm{C} 4-\mathrm{C} 1$ & 821 & 861 & 822 & 814 \\
\hline$v_{37}$ & $\begin{array}{l}\tau \mathrm{HCCC}(28) \text { in the ring } 1 \text { and ring } 3 \text { out of } \mathrm{H}+\gamma \mathrm{NNNC}(20) \text { in the } \mathrm{N} 1-\mathrm{N} 2-\mathrm{N} 3-\mathrm{C} 3+\gamma \mathrm{ONCC}(12) \text { in the } \\
\mathrm{O} 1-\mathrm{N} 2 \mathrm{C} 4-\mathrm{C} 1+\gamma \mathrm{CCNC}(10) \text { in the } \mathrm{C} 1-\mathrm{C} 2-\mathrm{N} 1-\mathrm{C} 3\end{array}$ & 737 & 728 & 742 & 745 \\
\hline$v_{38}$ & $\tau \mathrm{HCCC}(33)$ in the ring 3 out of $\mathrm{H}+\tau \mathrm{CCCC}(14)$ in the $\mathrm{C} 5-\mathrm{C} 6-\mathrm{C} 7-\mathrm{C} 8+\gamma \mathrm{CCCN}(11)$ in the $\mathrm{C} 8-\mathrm{C} 9-\mathrm{C} 10-\mathrm{N} 2$ & 721 & 728 & 727 & 729 \\
\hline$v_{39}$ & $\tau \mathrm{CCNC}(19)$ in the $\mathrm{C} 10-\mathrm{C} 5-\mathrm{N} 3-\mathrm{C} 3+\tau \mathrm{HCCC}(18)$ in the ring 3 out of $\mathrm{H}+\tau \mathrm{CCCC}(12)$ in the $\mathrm{C} 8-\mathrm{C} 9-\mathrm{C} 10-\mathrm{C} 5$ & 721 & 728 & 723 & 727 \\
\hline$v_{40}$ & $\mathrm{vFC}(21)$ in the $\mathrm{F}-\mathrm{C} 11+\delta \mathrm{CCC}(12)$ in the $\mathrm{C} 9-\mathrm{C} 10-\mathrm{C} 5+\delta \mathrm{FCF}(12)$ in the $\mathrm{F}-\mathrm{C} 11-\mathrm{F}$ & 721 & 728 & 721 & 716 \\
\hline$v_{41}$ & $\delta \mathrm{CCC}(17)$ in the $\mathrm{C} 9-\mathrm{C} 10-\mathrm{C} 5+\delta \mathrm{FCF}(13)$ in the $\mathrm{F}-\mathrm{C} 11-\mathrm{F}+\mathrm{vFC}(11)$ in the $\mathrm{F}-\mathrm{C} 11$ & 687 & 694 & 690 & 694 \\
\hline$v_{42}$ & $\gamma \mathrm{ONCC}(57)$ in the $\mathrm{O} 1-\mathrm{N} 2-\mathrm{C} 4-\mathrm{C} 1+\gamma \mathrm{CCNC}(16)$ in the $\mathrm{C} 1-\mathrm{C} 4-\mathrm{N} 2-\mathrm{C} 3$ & 687 & 694 & 688 & 691 \\
\hline$v_{43}$ & $\delta \mathrm{NCN}(18)$ in the $\mathrm{N} 2-\mathrm{C} 3-\mathrm{N} 3+\delta \mathrm{FCF}(14)$ in the $\mathrm{F}-\mathrm{C} 11-\mathrm{F}+\delta \mathrm{CCN}(10)$ in the $\mathrm{C} 10-\mathrm{C} 5-\mathrm{N} 3$ & 655 & 694 & 667 & 667 \\
\hline$v_{44}$ & $\begin{array}{l}\gamma \mathrm{NNNC}(40) \text { in the } \mathrm{N} 1-\mathrm{N} 2-\mathrm{N} 3-\mathrm{C} 3+\gamma \mathrm{ONCC}(18) \text { in the } \mathrm{O} 1-\mathrm{N} 2-\mathrm{C} 4-\mathrm{C} 1+\gamma \mathrm{CCNC}(11) \text { in the } \\
\mathrm{C} 1-\mathrm{C} 4-\mathrm{N} 2-\mathrm{C} 3\end{array}$ & 655 & 661 & 664 & 665 \\
\hline$v_{45}$ & $\delta \mathrm{CNC}(18)$ in the $\mathrm{C} 3-\mathrm{N} 2-\mathrm{C} 4+\delta \mathrm{OCC}(14)$ in the $\mathrm{O} 1-\mathrm{C} 4-\mathrm{C} 1+\delta \mathrm{NCN}(12)$ in the $\mathrm{N} 1-\mathrm{C} 3-\mathrm{N} 2$ & 615 & 661 & 630 & 630 \\
\hline$v_{46}$ & $\delta \mathrm{CCC}(30)$ in the $\mathrm{C} 6-\mathrm{C} 5-\mathrm{C} 10+\delta \mathrm{CCN}(13)$ in the $\mathrm{C} 1-\mathrm{C} 2-\mathrm{N} 1$ & 553 & 570 & 558 & 556 \\
\hline$v_{47}$ & $\begin{array}{l}\gamma \mathrm{CCCN}(24) \text { in the } \mathrm{C} 7-\mathrm{C} 6-\mathrm{C} 5-\mathrm{N} 3+\tau \mathrm{HCCC}(19) \text { in the ring 3out of } \mathrm{H}+\tau \mathrm{CCNC}(17) \text { in the } \\
\mathrm{C} 10-\mathrm{C} 5-\mathrm{N} 3-\mathrm{C} 3+\tau \mathrm{CCCC}(14) \text { in the } \mathrm{C} 6-\mathrm{C} 7-\mathrm{C} 8-\mathrm{C} 9\end{array}$ & 553 & & 555 & 551 \\
\hline$v_{48}$ & $\delta \mathrm{CNC}(21)$ in the $\mathrm{C} 2-\mathrm{N} 1-\mathrm{C} 3+\mathrm{vNC}(12)$ in the $\mathrm{N} 2-\mathrm{C} 3$ & 553 & & 554 & 551 \\
\hline$v_{49}$ & $\delta \mathrm{FCF}(23)$ in the $\mathrm{F}-\mathrm{C} 1-\mathrm{F}+\gamma \mathrm{FCFC}(20)$ in the $\mathrm{F} 1-\mathrm{C} 11-\mathrm{F} 3-\mathrm{C} 2+\mathrm{vFC}(12)$ in the $\mathrm{F}-\mathrm{C} 11$ & 530 & & 529 & 534 \\
\hline$v_{50}$ & $\delta \mathrm{FCF}(48)$ in the $\mathrm{F}-\mathrm{C} 11-\mathrm{F}+\gamma \mathrm{FCFC}(13)$ in the $\mathrm{F} 1-\mathrm{C} 11-\mathrm{F} 3-\mathrm{C} 2+\mathrm{vFC}(11)$ in the $\mathrm{F}-\mathrm{C} 11$ & 506 & & 502 & 509 \\
\hline$v_{51}$ & $\delta \mathrm{FCF}(23)$ in the $\mathrm{F}-\mathrm{C} 11-\mathrm{F}+\mathrm{vNC}(11)$ in the $\mathrm{N} 2-\mathrm{C} 3$ & 483 & 479 & 467 & 466 \\
\hline$v_{52}$ & $\tau \mathrm{HNCN}(61)$ in the ring 2 out of $\mathrm{H}$ & 441 & 422 & 451 & 445 \\
\hline$v_{53}$ & $\tau \mathrm{CCNC}(31)$ in the $\mathrm{C} 6-\mathrm{C} 5-\mathrm{N} 3-\mathrm{C} 3+\tau \mathrm{HNCN}(28)$ in the ring 2 out of $\mathrm{H}+\tau \mathrm{CNCC}(11)$ in the $\mathrm{C} 3-\mathrm{N} 2-\mathrm{C} 10-\mathrm{C} 9$ & 403 & 407 & 407 & 402 \\
\hline$v_{54}$ & $\begin{array}{l}\mathrm{vNC}(14) \text { in the } \mathrm{N} 2-\mathrm{C} 4+\mathrm{vCC}(11) \text { in the } \mathrm{C} 5-\mathrm{C} 10+\delta \mathrm{OCC}(11) \text { in the } \mathrm{O} 1-\mathrm{C} 4-\mathrm{C} 1+\delta \mathrm{CNC}(11) \text { in the } \\
\mathrm{C} 4-\mathrm{N} 2-\mathrm{C} 10+\delta \mathrm{FCF}(11) \text { in the } \mathrm{F}-\mathrm{C} 11-\mathrm{F}\end{array}$ & 403 & 407 & 398 & 396 \\
\hline$v_{55}$ & $\tau \mathrm{CNCC}(17)$ in the $\mathrm{C} 3-\mathrm{N} 2-\mathrm{C} 10-\mathrm{C} 9+\delta \mathrm{FCF}(15)$ in the $\mathrm{F}-\mathrm{C} 11-\mathrm{F}+\gamma \mathrm{CCCN}(14)$ in the $\mathrm{C} 7-\mathrm{C} 6-\mathrm{C} 5-\mathrm{N} 3$ & & 345 & 351 & 349 \\
\hline$v_{56}$ & $\delta \mathrm{FCF}(29)$ in the $\mathrm{F}-\mathrm{C} 11-\mathrm{F}+\delta \mathrm{OCC}(17)$ in the $\mathrm{O} 1-\mathrm{C} 4-\mathrm{C} 1+\gamma \mathrm{FCFC}(20)$ in the $\mathrm{F} 1-\mathrm{C} 11-\mathrm{F} 3-\mathrm{C} 2$ & & 345 & 331 & 334 \\
\hline$v_{57}$ & $\begin{array}{l}\gamma \mathrm{FCFC}(24) \text { in the } \mathrm{F} 1-\mathrm{C} 11-\mathrm{F} 3-\mathrm{C} 2+\gamma \mathrm{NNNC}(13) \text { in the } \mathrm{N} 1-\mathrm{N} 2-\mathrm{N} 3-\mathrm{C} 3+\tau \mathrm{CNCC}(13) \text { in the } \\
\mathrm{C} 3-\mathrm{N} 1-\mathrm{C} 2-\mathrm{C} 1+\delta \mathrm{FCF}(11) \text { in the } \mathrm{F}-\mathrm{C} 11-\mathrm{F}\end{array}$ & & 278 & 279 & 278 \\
\hline$v_{58}$ & $\begin{array}{l}\tau \mathrm{CCNC}(41) \text { in the } \mathrm{C} 9-\mathrm{C} 10-\mathrm{N} 2-\mathrm{C} 3+\gamma \mathrm{CCCN}(23) \text { in the } \mathrm{C} 7-\mathrm{C} 6-\mathrm{C} 5-\mathrm{N} 3+\tau \mathrm{CNCN}(17) \text { in the } \\
\mathrm{C} 10-\mathrm{N} 2-\mathrm{C} 3-\mathrm{N} 1\end{array}$ & & 278 & 268 & 266 \\
\hline$v_{59}$ & $\mathrm{vCC}(28)$ in the $\mathrm{C} 2-\mathrm{C} 11+\delta \mathrm{CNC}(14)$ in the $\mathrm{C} 2-\mathrm{N} 1-\mathrm{C} 3+\delta \mathrm{FCF}(14)$ in the $\mathrm{F}-\mathrm{C} 11-\mathrm{F}$ & & 278 & 262 & 265 \\
\hline$v_{60}$ & $\begin{array}{l}\delta \mathrm{CCN}(18) \text { in the } \mathrm{C} 9-\mathrm{C} 10-\mathrm{N} 2+\delta \mathrm{CNC}(16) \text { in the } \mathrm{N} 1-\mathrm{C} 3-\mathrm{N} 2+\gamma \mathrm{FCFC}(24) \text { in the } \\
\mathrm{F} 1-\mathrm{C} 11-\mathrm{F} 3-\mathrm{C} 2\end{array}$ & & 216 & 205 & 206 \\
\hline$v_{61}$ & $\tau \mathrm{CNCN}(40)$ in the $\mathrm{C} 4-\mathrm{N} 2-\mathrm{C} 3-\mathrm{N} 1+\tau \mathrm{CCNC}(28)$ in the $\mathrm{C} 1-\mathrm{C} 2-\mathrm{N} 1-\mathrm{C} 3$ & & 154 & 190 & 186 \\
\hline$v_{62}$ & $\tau \mathrm{CNCC}(31)$ in the $\mathrm{C} 10-\mathrm{N} 2-\mathrm{C} 4-\mathrm{C} 1+\tau \mathrm{CCNC}(25)$ in the $\mathrm{C} 1-\mathrm{C} 2-\mathrm{N} 1-\mathrm{C} 3+\gamma \mathrm{FCFC}(13)$ in the & & 154 & 130 & 129 \\
\hline
\end{tabular}


Table 2 (continued)

\begin{tabular}{|c|c|c|c|c|c|}
\hline \multirow[t]{2}{*}{$\begin{array}{l}\text { Vibration } \\
\text { no. }\end{array}$} & \multirow[t]{2}{*}{ Assignments } & \multicolumn{2}{|c|}{ Observed frequencies } & \multicolumn{2}{|c|}{$\begin{array}{l}\text { Calculated } \\
\text { frequencies in } \mathrm{cm}^{-1}\end{array}$} \\
\hline & & FT-IR & Laser-Ra. & B3LYP & M06-2X \\
\hline$v_{63}$ & $\delta \mathrm{CCN}(50)$ in the $\mathrm{C} 11-\mathrm{C} 2-\mathrm{N} 1+\gamma \mathrm{FCFC}(13)$ in the $\mathrm{F} 1-\mathrm{C} 11-\mathrm{F} 3-\mathrm{C} 2+\delta \mathrm{NCN}(12)$ in the $\mathrm{N} 2-\mathrm{C} 3-\mathrm{N} 3$ & & 116 & 126 & 126 \\
\hline$v_{64}$ & $\begin{array}{l}\gamma \mathrm{CCCN}(62) \text { in the } \mathrm{C} 2-\mathrm{C} 1-\mathrm{C} 4-\mathrm{N} 2+\tau \mathrm{CNCC}(11) \text { in the } \mathrm{C} 4-\mathrm{N} 2-\mathrm{C} 10-\mathrm{C} 5+\tau \mathrm{CNCN}(10) \text { in the } \\
\mathrm{C} 2-\mathrm{N} 1-\mathrm{C} 3-\mathrm{N} 3\end{array}$ & & 116 & 110 & 111 \\
\hline$v_{65}$ & $\begin{array}{l}\tau \mathrm{CNCC}(25) \text { in the } \mathrm{C} 3-\mathrm{N} 1-\mathrm{C} 2-\mathrm{C} 11+\tau \mathrm{CCNC}(13) \text { in the } \\
\mathrm{C} 6-\mathrm{C} 5-\mathrm{N} 3-\mathrm{C} 3+\gamma \mathrm{CCNC}(12) \text { in the } \mathrm{C} 9-\mathrm{C} 10-\mathrm{N} 2-\mathrm{C} 4+\gamma \mathrm{NNNC}(10) \text { in the } \\
\mathrm{N} 1-\mathrm{N} 2-\mathrm{N} 3-\mathrm{C} 3\end{array}$ & & & 48 & 47 \\
\hline $\begin{array}{l}v_{66} \\
R^{2}\end{array}$ & $\tau \mathrm{FCCC}(90)$ in the $\mathrm{F} 1, \mathrm{~F} 2, \mathrm{~F} 3-\mathrm{C} 11-\mathrm{C} 2-\mathrm{C} 1$ & & & $\begin{array}{l}26 \\
0.9996\end{array}$ & $\begin{array}{l}27 \\
0.9993\end{array}$ \\
\hline
\end{tabular}

$v$, stretching; $\delta$, in-plane bending; $\gamma$, out-of-plane bending; $\tau$, torsion.

Potential energy distribution (PED), less than $10 \%$ are not shown.

FT-IR spectrum. However, these modes have not been observed in Laser-Raman spectrum. Theoretical symmetric modes have been calculated at $3112 / 3088$ and $3076 / 3057 \mathrm{~cm}^{-1}$ in B3LYP/M06-2X methods. Theoretical asymmetric stretching modes have been calculated at 3067/3047 and 3055/3037 with same methods. Substitution sensitive $\mathrm{C}-\mathrm{H}$ plane bending vibrations lie in the region $1300-1000 \mathrm{~cm}^{-1}$ [47]. In this study in-plane bending vibrations have been observed at 1456(IR)/1478(Ra), 1353(IR)/1373(Ra), 1329(IR)/1296(Ra), 1246(IR)/1253(Ra), 1139(IR)/1148(Ra), 1095(IR)/1091(Ra) and 993(IR)/1029(Ra) $\mathrm{cm}^{-1}$. These modes have been calculated at 1459/1461, 1438/1440,1345/1341, 1300/ $1288,1224 / 1219,1137 / 1176,1131 / 1142,1088 / 1084$ and 994/
$995 \mathrm{~cm}^{-1}$ in B3LYP/M06-2X methods. Band involving the out of plane $\mathrm{C}-\mathrm{H}$ vibrations appear in the range $1000-675 \mathrm{~cm}^{-1}$ [47]. In this study, out of plane vibrations have been observed at 926(IR)/971(Ra), 821(IR)/861(Ra), 737(IR)/728(Ra) and 553(Ra) $\mathrm{cm}^{-1}$, and calculated at 953/958, 918/927, 833/840, 742/745, $727 / 729,723 / 727$ and $555 / 551 \mathrm{~cm}^{-1}$ in B3LYP/M06-2X methods with $6-311++G(d, p)$ basis set.

The ring carbon-carbon stretching vibrations occur in the region $1625-1430 \mathrm{~cm}^{-1}$. In general, the bands are of variable intensity and are observed at 1625-1590, 1590-1575, 1540-1470, and $1465-1430$ and $1380-1280 \mathrm{~cm}^{-1}$ from the wavenumber ranges given [56-59]. In the present work, the wavenumbers observed in
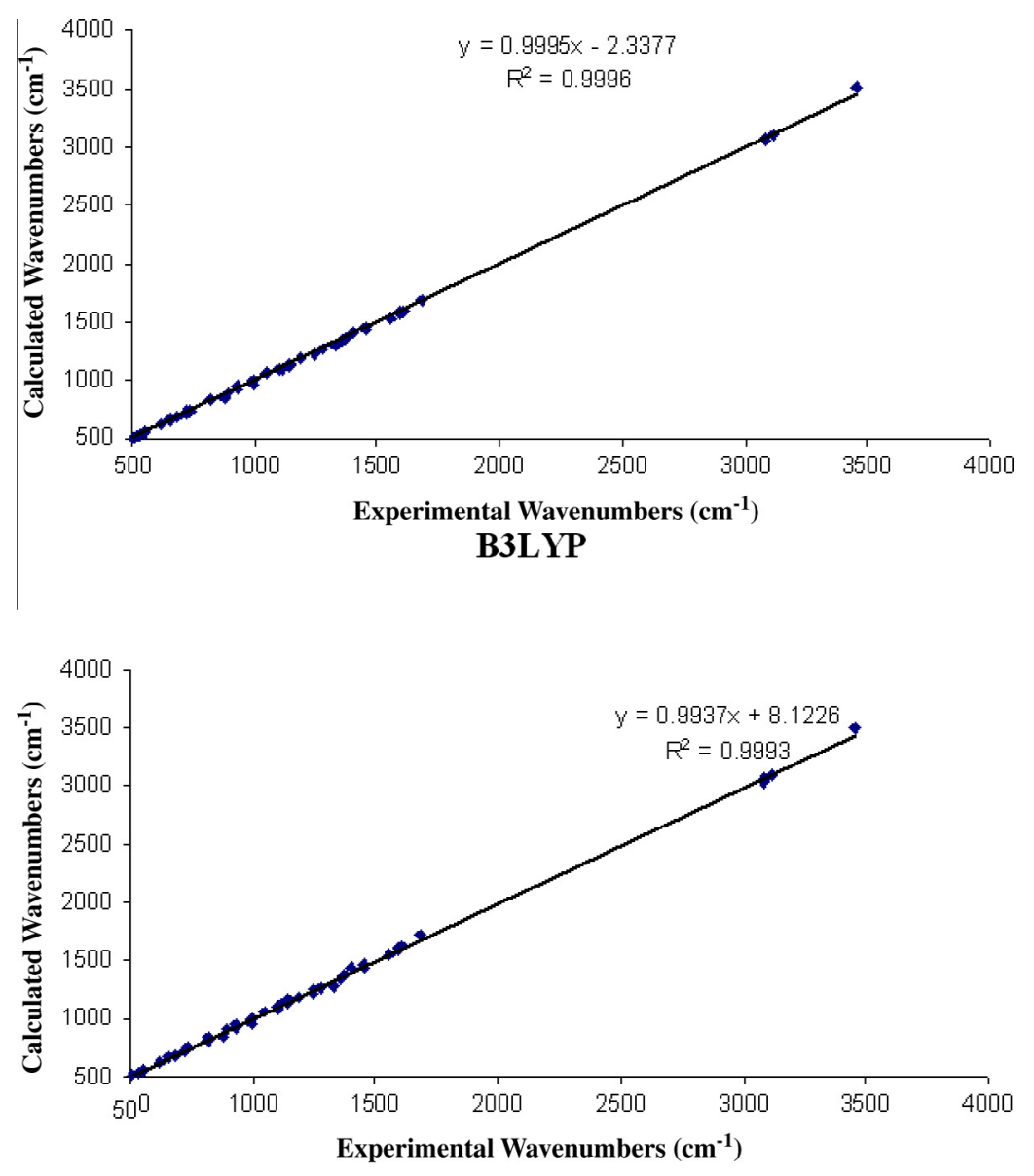

M06-2X

Fig. 4. Correlation graphics of experimental and theoretical (scaled) wavenumbers of the title compound. 
FT-IR/Laser-Raman spectra at 1609/1612, 1590/1588, 1456/1478, $1373 / 1373,1353 / 1373,1329 / 1296,1279 / 1253$ and $993 /$ $1029 \mathrm{~cm}^{-1}$ have been assigned to $\mathrm{C}-\mathrm{C}$ stretching vibrations. The theoretical computed values in B3LYP/M06-2X at 15978/1618, 1588/1611, 1576/1597, 1459/1461, 1361/1370, 1345/1341, 1300/ $12881259 / 1269$ and $994 / 995 \mathrm{~cm}^{-1}$ (nine bands). The PED corresponding to all $\mathrm{C}-\mathrm{C}$ vibrations lies between $11 \%$ and $54 \%$ as shown in Table 2. These $\mathrm{C}-\mathrm{C}$ stretching modes have been observed at 1589 and $1516 \mathrm{~cm}^{-1}$ in FT-IR and 1596 and $1541 \mathrm{~cm}^{-1}$ in FT-Raman spectra by Rofouei et al. [57]. All these calculated values are in good agreement with the experimental data. The remainder of the observed and calculated wavenumbers and assignments of present molecule are shown in Table 2.

The correlation graphic which describes harmony between the calculated and experimental wavenumbers is shown in Fig. 4. As can be seen from Fig. 4, the experimental fundamentals have good correlation with B3LYP. The relations between the calculated and experimental wavenumbers are linear and described by the following equation:

$$
\begin{aligned}
& v_{\text {Cal }}=0.9995 v_{\text {exp }}-2.3377 \text { for B3LP method } \\
& v_{\text {Cal }}=0.9937 v_{\text {exp }}+8.1226 \text { for M06-2X method }
\end{aligned}
$$

We calculated $R^{2}$ values $\left(R^{2}=0.9996\right.$ for B3LYP and $R^{2}=0.9993$ for M06-2X) between the calculated and experimental wavenumbers. As a result, the performances of the B3LYP method with respect to the prediction of the wavenumbers within the molecule were quite close.

\section{Homo-Lumo analysis}

Many organic molecules containing conjugated $\pi$ electrons have been characterized as hyperpolarizabilities and researched by means of vibrational spectroscopy. The $\pi$ electron cloud moment from donor to acceptor can make the molecule highly polarized through the single-double path when it changes from the ground state to the excited state. Both the highest occupied molecular orbital (HOMO) and the lowest unoccupied molecular orbital (LUMO) are the main orbitals taking part in chemical stability. The HOMO represents the ability to donate an electron, LUMO as an electron acceptor represents the ability to obtain an electron [60]. The LUMO and HOMO energies have been calculated by
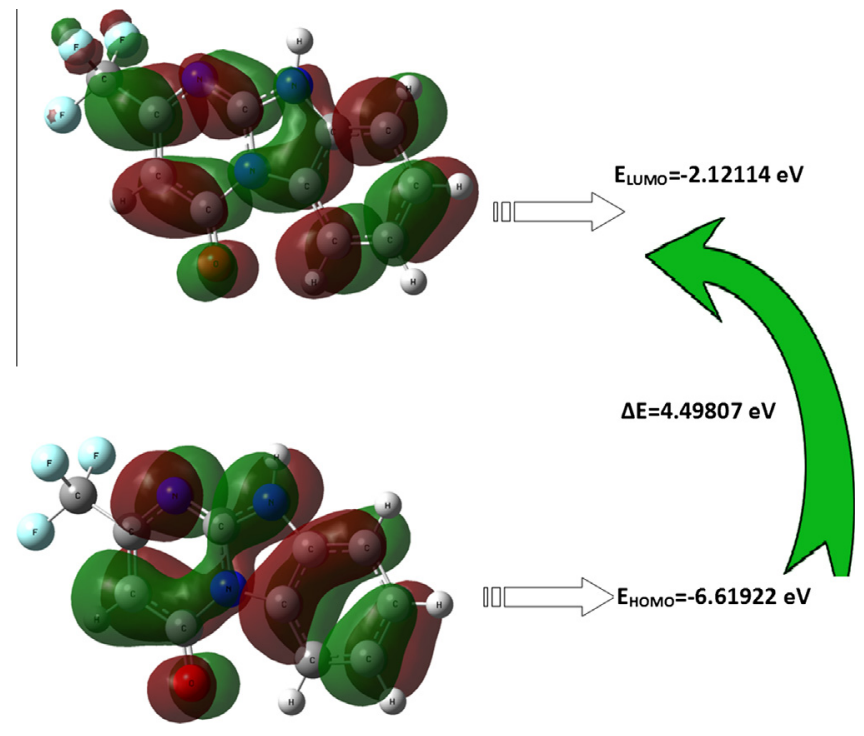

Fig. 5. Calculated HOMO-LUMO plots of the title compound.
Table 3

Comparison of HOMO-LUMO energy gaps and related molecular properties of the title compound.

\begin{tabular}{lcc}
\hline Molecular properties & B3LYP/6-311++G(d,p) & M06-2X/6-311++G(d,p) \\
\hline Energies (a.u) & -962.09895620 & -961.75930183 \\
$E_{\text {HOMO }(\mathrm{eV})}$ & -6.61922 & -7.82496 \\
$E_{\mathrm{LUMO}}(\mathrm{eV})$ & -2.12114 & -1.11132 \\
Energy Gap $(\mathrm{eV})$ & 4.49807 & 6.71364 \\
Ionization potential $(I)$ & 6.61922 & 7.82496 \\
Electron affinity $(A)$ & 2.12114 & 1.11132 \\
Global hardness $(\eta)$ & 2.24903 & 3.35682 \\
Chemical potential $(\mu)$ & 4.37018 & 4.46814 \\
Electrophilicity $(\psi)$ & 4.24500 & 2.97150 \\
Softness $(\zeta)$ & 0.44463 & 0.29790 \\
Dipol moment $($ debye $)$ & 6.0886 & 5.9677 \\
\hline
\end{tabular}

B3LYP/6-311++G(d,p) and M06-2X/6-311++G(d,p) methods, and depicted in Fig 5 . Considering the chemical hardness, large HOMO-LUMO gap means a hard molecule and small HOMOLUMO gap means a soft molecule. One can also relate the stability of the molecule to hardness, which means that molecule with least HOMO-LUMO gap means it is more reactive [61]. The frontier molecules orbital, HOMO and LUMO and frontier orbital energy gap helping to exemplify the reactivity and kinetic stability of molecules are important parameters in the electronic studies [62,63]. The analysis of the wave function indicates that the electron absorption corresponding to the transition from the ground state to the first excited state is mainly defined by one electron excitation from the highest occupied orbital (HOMO) to the lowest unoccupied orbital (LUMO) [64].

The calculated energy of the title compound is -962.09895620 a.u in B3LYP/6-311++G(d,p) and -961.75930183 a.u in M06-2X/6$311++G(d, p)$. Meanwhile, the lowering of the energy gap describes that the eventual charge transfer takes place within the molecule. The HOMO-LUMO energy gap calculated at B3LYP and M06-2X/6$311++G(d, p)$ level reflect the chemical activity of the molecule and explain the eventual charge transfer interaction within the molecule, which influences the biological activity of the molecule. The positive phase is represented in red color and the negative phase is represented in green color. HOMO-LUMO plots are shown in Fig. 5. As seen from the figures, the HOMO is located on ring 1, ring 2 and ring 3, but on $\mathrm{CF}_{3}$ group was not observed, the LUMO is more focused on all of the molecules.

Associated within the framework of molecular orbital theory, the ionization energy and electron affinity can be expressed by HOMO and LUMO orbital energies as $I=-E_{\mathrm{HOMO}}$ and $A=-E_{\mathrm{LUMO}}$. The global hardness, $\eta=1 / 2\left(E_{\mathrm{LUMO}}-E_{\text {Hомо }}\right)$. The electron affinity can be used in combination with ionization energy to give electronic chemical potential, $\mu=1 / 2\left(E_{\mathrm{LUMO}}+E_{\mathrm{HOMO}}\right)$. The global electrophilicity index, $\psi=\mu^{2} / 2 \eta$ and softness, $\zeta=1 / \eta[65,66]$. These parameters have been evaluated and tabulated in Table 3.

\section{Conclusion}

In this study, the vibrational analysis of a newly synthesized bioactive agent, 2-Trifluoromethyl-10H-benzo[4,5]-imidazo[1,2a]pyrimidin-4-one molecule has been studied by experimental (FT-IR and Laser-Raman spectra) and theoretical (DFT/B3LYP and M06-2X) methods. The optimized geometric parameters, vibrational harmonic frequencies, PED assignments, molecular orbital energies and other properties (related with HOMO and LUMO energy values) of the compound have been calculated by using DFT/B3LYP and M06-2X methods with $6-311++G(d, p)$ basis set. The theoretical optimized geometric parameters (bond lengths and angles) and vibrational frequencies are compared with the experimental data. Considerable level of correlation has been 
noticed. The detailed PED\% analysis of the compound showed a good agreement with the experimental data. The calculated HOMO and LUMO along with their plot has been presented for understanding of charge transfer occuring within the molecule. These results are taken into account; we conclude that the title compound is an attractive object for future medicinal and pharmacological studies to evaluate its therapeutical importance.

\section{References}

[1] Y. Li, C. Tan, C. Gao, C. Zhang, X. Luan, X. Chen, H. Liu, Y. Chen, Y. Jiang, Bioorg. Med. Chem. 19 (2011) 4529-4535.

[2] K. Starcevic, M. Kralj, K. Ester, I. Sabol, M. Grec, K. Pavelic, G.K. Zamola, Bioorg. Med. Chem. 15 (2007) 4419-4426.

[3] T. Gazivoda, M. Sokcevic, M. Kralj, L. Suman, K. Pavelic, E.D. Clercq, G. Andrei, R. Snoeck, J. Balzarini, M. Mintas, S.R. Malic, J. Med. Chem. 50 (2007) 4105-4112.

[4] S. Noll, M. Kralj, L. Suman, H. Stephan, I. Piantanid, Eur. J. Med. Chem. 44 (2009) 1172-1179.

[5] K.B. Puttaraju, K. Shivashankar, Chandra, M. Mahendra, V.P. Rasal, P.N. Venkatavivek, N. Ponnuru, K. Rai, M.B. Chanu, Eur. J. Med. Chem. 69 (2013) 316-322.

[6] Chandra, K.B. Puttaraju, K. Shivashankar, E.A. Jithesh Babu, M. Mahendra, Acta Cryst. E69 (2013) o1536.

[7] M.A. Palafox, V.K. Rastogi, R.P. Tanwar, L. Mittal, Spectrochim. Acta A 59 (2003) 2473-2486.

[8] S. Mohan, N. Sundaraganesan, J. Mink, Spectrochim. Acta A 47 (1991) 1111 1115.

[9] G.N. Ten, V.V. Nechaev, A.N. Pankratov, V.I. Berezin, V.I. Baranov, J. Struct. Chem. 51 (2010) 854-861.

[10] Ç. Çırak, N. Koç, J. Mol. Model 18 (2012) 4453-4464.

[11] M.A. Palafox, G. Tardajos, A. Guerrero-Martinez, V.K. Rastogi, D. Mishra, S.P. Ojha, W. Kiefer, Chem. Phys. 340 (2007) 17-31.

[12] M. Szczesniak, M.J. Nowak, K. Szczepaniak, W.B. Person, Spectrochim. Acta A 41 (1985) 237-250.

[13] J.S. Singh, J. Mol. Struct. 876 (2008) 127-133.

[14] M.H. Jamróz, J.C. Dobrowolski, R. Brzozowski, J. Mol. Struct. 787 (2006) 172183.

[15] C. Çırak, Y. Sert, F. Ucun, Spectrochim. Acta A 92 (2012) 406-414.

[16] Y. Zhao, D.G. Truhlar, Theor. Chem. Account. 120 (2008) 215-241.

[17] K. Helios, R. Wysokiński, A. Pietraszko, D. Michalska, Vib. Spectrosc. 55 (2011) 207-215.

[18] J. Gu, J. Wang, J. Leszczynski, Chem. Phys. Lett. 512 (2011) 108-112.

[19] K.H. Lemke, T.M. Seward, Chem. Phys. Lett. 573 (2013) 19-23.

[20] E.I. Paulraj, S. Muthu, Spectrochim. Acta A 108 (2013) 38-49.

[21] U. Yadava, M. Singh, M. Roychoudhury, Comput. Theor. Chem. 977 (2011) 134139.

[22] C.N. Ramachandran, E. Ruckenstein, Comput. Theor. Chem. 973 (2011) 28-32.

[23] Y. Sert, C. Çrak, F. Ucun, Spectrochim. Acta A 107 (2013) 248-255.

[24] A. Frish, A.B. Nielsen, A.J. Holder, Gauss View User Manual, Gaussian Inc., Pittsburg, PA, 2001.

[25] W.H. James, E.G. Buchanan, C.W. Müller, J.C. Dean, D. Kosenkov, L.V. Slipchenko, L. Guo, A.G. Reidenbach, S.H. Gellman, T.S. Zwier, J. Phys. Chem. A115 (2011) 13783-13798.

[26] M.J. Frisch, G.W. Trucks, H.B. Schlegel, G.E. Scuseria, M.A. Robb, J.R. Cheeseman, G. Scalmani, V. Barone, B. Mennucci, G.A. Petersson, H. Nakatsuji, M. Caricato, X. Li, H.P. Hratchian, A.F. Izmaylov, J. Bloino, G. Zheng, J.L. Sonnenberg, M. Hada, M. Ehara, K. Toyota, R. Fukuda, J. Hasegawa, M. Ishida, T. Nakajima, Y. Honda, O. Kitao, H. Nakai, T. Vreven, J.A. Montgomery Jr., J.E. Peralta, F. Ogliaro, M. Bearpark, J.J. Heyd, E. Brothers, K.N. Kudin, V.N. Staroverov, R. Kobayashi, J. Normand, K. Raghavachari, A. Rendell, J.C. Burant, S.S. Iyengar, J. Tomasi, M. Cossi, N. Rega, J.M. Millam, M. Klene, J.E. Knox, J.B. Cross, V. Bakken, C. Adamo, J. Jaramillo, R. Gomperts, R.E. Stratmann, O. Yazyev, A.J. Austin, R. Cammi, C. Pomelli, J.W. Ochterski, R.L. Martin, K. Morokuma, V.G. Zakrzewski, G.A. Voth,
P. Salvador, J.J. Dannenberg, S. Dapprich, A.D. Daniels, Ö. Farkas, J.B. Foresman, J.V. Ortiz, J. Cioslowski, D.J. Fox, Gaussian 09, Revision A1, Gaussian, Inc. Wallingford CT, 2009.

[27] M.H. Jamróz, Vibrational Energy Distribution Analysis VEDA 4, Warsaw, 2004.

[28] M.H. Jamróz, Spectrochim. Acta A 114 (2013) 220-230.

[29] H. Arslan, Ö. Algül, Spectrochim. Acta A 70 (2008) 109-116.

[30] Ç. Çırak, S. Demir, F. Ucun, O. Çubuk, Spectrochim. Acta A 79 (2011) 529-532.

[31] A.A.M. Abdel-Hazel, Arch. Pharm. Res. 30 (2007) 678-684.

[32] J.J. Nunes, X.T. Zhou, P. Amouzeng, C. Ghiron, D.N. Johnston, E.C. Power, WO Patent No. 2005009 443, 2005.

[33] F. Palacious, C. Alanso, D. Aparicio, G. Rubiales, J.M. Santos, Tetrahedron 63 (2007) 523-575.

[34] E. Duval, A. Case, R.L. Stein, G.D. Cunny, Bioorg. Med. Chem. Lett. 15 (2005) 1885-1889.

[35] M.B. Teimouria, R. Bazhrang, Bioorg. Med. Chem. Lett. 16 (2006) 3697-3701.

[36] Y. Ping, W. Yan, D. Zheng-Chao, S. Yu, N. Guang-Hua, S. Xin-Jian, T. Da-Ting, Chinese J. Struct. Chem. 32 (2013) 1023-1030.

[37] V. Krishnakumar, N. Prabavathi, Spectrochim. Acta A 71 (2008) 449-457.

[38] U. Rani, H. Oturak, S. Sudha, N. Sundaraganesan, Spectrochim. Acta A 78 (2011) 1467-1475.

[39] G. Ramachandran, S. Muthu, J.U. Maheswari, Solid State Sci. 16 (2013) 45-52.

[40] E. İnkaya, S. Günnaz, N. Özdemir, O. Dayan, M. Dinçer, B. Çetinkaya, Spectrochim. Acta A 103 (2013) 255-263.

[41] A. Ünal, B. Eren, Spectrochim. Acta A 114 (2013) 129-136.

[42] T. Tang, G. Tang, S. Kou, J. Zhao, L.F. Culnane, Y. Zhang, Spectrochim. Acta A 117 (2014) 144-151.

[43] S. Ramalingam, S. Periandy, S. Mohan, Spectrochim. Acta A 77 (2010) 73-81.

[44] D. Lin-Vien, N.B. Colthup, W.G. Fateley, J.G. Graselli, The Handbook of Infrared and Raman Characteristic Frequencies of Organic Molecules, Academic Press, Boston, MA, 1991.

[45] T. Rajamani, S. Muthu, Solid State Sci. 16 (2013) 90-101.

[46] N. Sundaraganesan, K. Satheshkumar, C. Meganathan, B.D. Joshua, Spectrochim. Acta A 65 (2006) 1186-1196.

[47] G. Socrates, Infrared and Raman Characteristic Group Frequencies, Tables and Charts, third ed., Wiley, Chichester, 2001.

[48] L.E. Fernandez, A.B. Altabef, A. Navarro, M. Fernandez, Gomez, E.L. Varetti, Spectrochim. Acta A 56 (2000) 1101.

[49] L.E. Fernandez, A.B. Altabef, E.L. Varetti, J. Mol. Struct. 612 (2002) 1-11.

[50] V. Krishnakumar, R. Ramasamy, Spectrochim. Acta A 69 (2008) 8-17.

[51] M. Arivazhagan, S. Jeyavijayan, Spectrochim. Acta A 79 (2011) 161-168.

[52] V. Krishnakumar, N. Prabavathi, Spectrochim. Acta A 77 (2010) 238-247.

[53] N. Puviarasan, V. Arjunan, S. Mohan, Turkey J. Chem. 26 (2002) 323.

[54] G. Varsanyi, Vibrational Spectra of Benzene Derivatives, Academic Press, New York, 1969.

[55] V. Krishnakumar, R.J. Xavier, Indian J. Pure Appl. Phys. 41 (2003) 597.

[56] M. Silverstein, G. Clayton Bassler, C. Morrill, Spectrometric Identification of Organic Compounds, Wiley, New York, 1981.

[57] M.K. Rofouei, N. Sohrabi, M. Shamsipur, E. Fereyduni, S. Ayyapan, N Sundaraganesan, Spectrochim. Acta A 76 (2010) 182-190.

[58] N.P. Roeges, A Guide to complete Interpretation of Infrared Spectra of Organic Structures, Wiley, New York, 1994.

[59] G. Varsayani, Assigmentts for Vibrational Spectra of Seven Benzene Derivatives, vol. 1, Adam Hilger, London, 1974.

[60] E. Kavitha, N. Sundaraganesan, S. Sebastian, M. Kurt, Spectrochim. Acta A 77 (2010) 612-619.

[61] K. Chaitanya, Spectrochim. Acta A 86 (2012) 159-173.

[62] E. Kavitha, N. Sundaraganesan, S. Sebastian, Indian J. Pure Appl. Phys. 48 (2010) 20-30.

[63] A. Jayaprakash, V. Arjunan, S. Mohan, Spectrochim. Acta A 81 (2011) 620-630.

[64] S. Subashchandrabose, H. Saleem, Y. Erdogdu, G. Rajarajan, V. Thanikachalam, Spectrochim. Acta A 82 (2011) 260-269.

[65] T. Vijayakumar, I. Hubert Joe, C.P.R. Nair, V.S. Jayakumar, Chem. Phys. 343 (2008) 83-99.

[66] M. Govindarajan, M. Karabacak, A. Suvitha, S. Periandy, Spectrochim. Acta A 89 (2012) 137-148. 